\title{
PROCTOLIN IN THE LOBSTER: THE DISTRIBUTION, RELEASE, AND CHEMICAL CHARACTERIZATION OF A LIKELY NEUROHORMONE ${ }^{1}$
}

\author{
THOMAS L. SCHWARZ, ${ }^{2}$ GRACE M. -H. LEE, KATHLEEN KING SIWICKI, \\ DAVID G. STANDAERT, AND EDWARD A. KRAVITZ ${ }^{3}$
}

Department of Neurobiology, Harvard Medical School, Boston, Massachusetts 02115

Received August 4, 1983; Revised November 21, 1983; Accepted November 22, 1983

\begin{abstract}
A radioimmunoassay, immunohistochemical techniques, and high pressure liquid chromatography (HPLC) methods have been developed for the study of the pentapeptide proctolin in the lobster Homarus americanus. Proctolin-like immunoreactivity is present in nearly every portion of the lobster nervous system; immunoreactivity is found in the brain, in each of the ganglia and connectives of the ventral nerve cord, and in many of the nerve roots that emerge from the cord. The greatest amounts are found in the pericardial organs, which are well known neurosecretory structures, and these structures have been selected for more detailed study.

The immunoreactive material in the pericardial organs appears to be authentic proctolin. This material co-migrates with synthetic proctolin in two HPLC systems. Furthermore, a peptide that is purified from pericardial organs by HPLC is indistinguishable from synthetic proctolin in high resolution fast atom bombardment mass spectrometry. Cytochemistry reveals that the surface of the pericardial organs is densely covered with immunoreactive varicosities. No cell bodies that stain for proctolin are found in the pericardial organs, and the cells that give rise to the varicosities have not yet been located. The nerve endings in pericardial organs are capable of releasing proctolin-like material when depolarized in the presence of $\mathrm{Ca}^{++}$. These findings suggest that proctolin is a neurohormone in the lobster.
\end{abstract}

Proctolin (Arg-Tyr-Leu-Pro-Thr) was originally isolated from the hindgut of the cockroach, Periplaneta americana (Brown and Starratt, 1975; Starratt and Brown, 1975) and has since been found in many insect species (Brown, 1977; Holman and Cook, 1979a, b; O'Shea and Adams, 1981). Antibodies to the peptide have been used for cytochemical localization of proctolin-like material in individual neurons of Periplaneta (Eckert et al., 1981; Bishop et al., 1981; Bishop and O'Shea, 1982; O'Shea and Bishop, 1982). Proctolin causes or enhances

'We are grateful to Steven A. Martin and Dr. Catherine E. Costello of the Massachusettes Institute of Technology in whose laboratory the mass spectrometry was performed (National Institutes of Health Grant RR00317 to K. Biemann) and to Dr. Barabara Beltz for her instruction in histochemical procedures. We would like to thank Lisa Halvorson and Charlotte Menzel for excellent technical assistance. We also thank Dee Cox, Sarah Luria, Bruce Lister, Michael Lafratta, and Joseph Gagliardi for their help. This work was supported by National Institutes of Health Grants NS07848 and NS02253. T. L. S. was supported by National Institutes of Health Training Grant NS07112.

${ }^{2}$ Present address: Department of Physiology, University of California, San Francisco, CA 94143.

${ }^{3}$ To whom correspondence should be addressed. contractions in several insect muscles (Brown, 1975; Piek and Mantel, 1977; Cook and Meola, 1978; May et al., 1979; Piek et al., 1979; Irving and Miller 1980; Adams and O'Shea, 1983) and changes the firing pattern of neurons in insect ganglia (Walker et al., 1980).

Proctolin-like material has also been found in Crustacea. In particular, it is associated with well known neurosecretory structures, the pericardial organs (Alexandrowicz, 1953). Like the vertebrate neurohypophysis, the pericardial organs are rich in nerve terminals and are exposed to the circulatory system of the animal (Maynard and Maynard, 1962; Sullivan et al., 1977). The amines serotonin, octopamine, and dopamine are present in pericardial organs, along with a number of peptide hormones (Maynard and Welsh, 1959; Belamarich and Terwilliger, 1966; Berlind and Cooke, 1970; Cooke and Goldstone, 1970; Evans et al., 1976a, b; Sullivan et al., 1977; Livingstone et al., 1981; Beltz and Kravitz, 1983). Evidence that one of these hormones resembles proctolin has been obtained in three crustacean species. A peptide resembling proctolin in thin layer chromatography and paper electrophoresis was extracted from pericardial organs of Cardisoma carnifex and was found to mimic 
proctolin in a bioassay on the cockroach hindgut (Sullivan, 1979). Proctolin-like material has been found by radioimmunoassay in the pericardial organs of Panulirus interruptus, C. carnifex, and Cancer magister (Kingan, 1980). Immunoreactivity was also found in central ganglia from $P$. interruptus, Pacifasticus leniusculus, C. magister, and Homarus americanus (Kingan, 1980; Kingan and Titmus, 1983).

Actions of proctolin in crustacean tissues resemble those of the amine neurohormones, serotonin, octopamine, and dopamine. Proctolin strengthens the heart beat of the crab Portunus sanguinolentus (Sullivan, 1979) and the lobster $H$. americanus (Miller and Sullivan, 1981) and enhances contractions of stomatogastric muscles in $P$. interruptus (Lingle, 1979). In addition, proctolin causes a long-lasting contracture of the dactyl opener muscle of the walking legs of Homarus americanus (Kravitz et al., 1980; Schwarz et al., 1980).

These findings have motivated us (1) to determine if Homarus contains authentic proctolin, (2) to study the distribution and cytochemical localization of proctolin and proctolin-like material in the lobster, and (3) to inquire whether such material is released from nervous tissue and circulates as a neurohormone in the hemolymph. Toward these goals we have raised antibodies to proctolin, established a radioimmunoassay (RIA), and developed immunohistochemical procedures. In addition, high pressure liquid chromatography (HPLC) and mass spectrometry were used to purify and characterize the proctolin-like material extracted from pericardial organs of Homarus.

\section{Materials and Methods}

We obtained materials from the following sources: proctolin, $\left[{ }^{3} \mathrm{H}\right]$ proctolin, and the molluscan cardioexcitatory peptide FMRF-amide (Peninsula Laboratories); RIA grade bovine serum albumin (BSA), $\alpha$-melanocytestimulating hormone, oxytocin, substance $\mathrm{P}$, octopamine- $\mathrm{HCl}$, serotonin creatinine sulfate, and Triton $\mathrm{X}$ 100 (Sigma); paraformaldehyde (Fisher); sodium cacodylate (Balzers); 1-ethyl-3-(3-dimethylaminopropyl)carbodiimide, leucine-enkephalin, eledoisin-related peptide, neurotensin, physalaemin, and Freund's complete adjuvant (Calbiochem); glutaraldehyde (Tousimis Research Corp.); $\mathrm{Na}^{125} \mathrm{I}$ (New England Nuclear); high purity water and acetonitrile (Burdick and Jackson); high purity methanol (MCB); trifluoroacetic acid (Pierce); normal goat serum (GIBCO); fluorescein-conjugated goat anti-rabbit antibody (Boehringer-Mannheim); somatostatin, eledoisin, and methionine-enkephalin were the gift of Dr. Susan Leeman.

Proctolin iodination. Proctolin $(0.5 \mu \mathrm{g}$ in $10 \mu \mathrm{l}$ of $0.1 \mathrm{M}$ sodium borate, $\mathrm{pH} 10$ ) was combined with $0.5 \mathrm{mCi}$ of $\mathrm{Na}^{125} \mathrm{I}$ in $5 \mu \mathrm{l} 0.1 \mathrm{~N} \mathrm{NaOH}$. The iodination was initiated with $5 \mu \mathrm{l}$ of dilute hypochlorite solution $(20 \mu \mathrm{l}$ of Clorox (Proctor \& Gamble) in $13.3 \mathrm{ml}$ of borate buffer). After $15 \mathrm{sec}$ the reaction was stopped with $20 \mu \mathrm{l}$ of sodium metabisulfite $(10 \mathrm{mg} / \mathrm{ml}$ in borate buffer), and $2 \mathrm{~min}$ later $20 \mu \mathrm{l}$ of $\mathrm{NaI}(100 \mathrm{mg} / \mathrm{ml}$ in $60 \%$ acetic acid) were added. After another $2 \mathrm{~min}, 50 \mu \mathrm{l}$ of $0.25 \% \mathrm{BSA}$ in 0.05 $\mathrm{N}$ sodium phosphate ( $\mathrm{pH} 7.6$ ) were added and the reaction mixture was applied to a Sephadex G-10 column which had been prepared in a siliconized Pasteur pipette and prewashed with RIA buffer (see below) and 10\% acetic acid. Material was eluted from the column with $10 \%$ acetic acid, and $0.5-\mathrm{ml}$ fractions were collected, counted, and tested for proctolin immunoreactivity. Iodinated proctolin was generally found in the third milliliter of effluent. These fractions were diluted with an equal volume of $60 \% n$-propanol and stored at $4^{\circ} \mathrm{C}$.

Production of antisera. Because proctolin is too small to provoke an immune response, it was necessary to produce an antigen by coupling the peptide to a larger carrier protein. We tried a variety of antigens, doses, and injection procedures and successfully obtained antisera to proctolin from four rabbits. The binding of iodinated proctolin to dilutions of these antisera are shown in Figure 1.

Antiserum $D$, with which the RIA was established (see below), was produced by one of eight New Zealand White rabbits injected with a carbodiimide-cross-linked proctolin-BSA conjugate made by an adaptation of the method of Goodfriend et al. (1964). Two hundred fifty microliters of $80 \mathrm{mg} / \mathrm{ml}$ 1-ethyl-3-(3-dimethylaminopropyl) carbodiimide were added to $0.5 \mathrm{ml}$ of water containing $2.0 \mathrm{mg}$ of proctolin, $4.0 \mathrm{mg}$ of BSA, and approximately $20,000 \mathrm{cpm}$ of $\left[{ }^{125} \mathrm{I}\right]$ proctolin with which to check the efficiency of the cross-linking. This solution was incubated overnight and then dialyzed against 1 liter of $0.9 \%$ $\mathrm{NaCl}$ for $24 \mathrm{hr}$ at $4^{\circ} \mathrm{C}$. Finally, the antigen was diluted to $20 \mathrm{ml}$ with distilled water. Approximately $65 \%$ of the $\left[{ }^{125} \mathrm{I}\right]$ proctolin was incorporated into the conjugate. For immunizations, the antigen was emulsified with an equal volume of Freund's complete adjuvant. The muscles of the hindlegs of the rabbits were injected with $1 \mathrm{ml}$ of the emulsion initially and with half that amount once a month thereafter. One week after each injection, the rabbits were bled from the lateral ear vein or central ear artery.

Antiserum $A$ was obtained from one of three rabbits injected with a glutaraldehyde-cross-linked proctolinBSA conjugate. Immunocytochemical techniques were developed with antiserum $A$ (see below) because proctolin in aldehyde-fixed tissue was likely to resemble a glutaraldehyde-conjugated antigen. The antigen was prepared by an adaptation of the method of Miller et al. (1978). Ten microliters of $50 \%$ glutaraldehyde were added to $0.2 \mathrm{ml}$ of $0.1 \mathrm{M}$ sodium phosphate $(\mathrm{pH} 7.4)$ containing $2.0 \mathrm{mg}$ of proctolin, $4.0 \mathrm{mg}$ of BSA, and 20,000 cpm of [ $\left.{ }^{125} \mathrm{I}\right]$ proctolin. This was incubated and dialyzed as described above and then was diluted to $2 \mathrm{ml}$ with distilled water. The efficiency of incorporation of the peptide into the conjugate was approximately $50 \%$. Injections and bleedings were as described above for antiserum $D$.

Recently, two rabbits were injected with a proctolinthyroglobulin conjugate. Although their sera have not been used for the experiments reported in this paper, it is of interest that both animals have high titers of antibodies to proctolin ( $G r$ and $E t$ in Fig. 1). We do not know if the success of these immunizations was due to the antigen or to a more frequent schedule of injections. The antigen was made according to a modification of the method of Skowsky and Fisher (1972). Two hundred fifty 


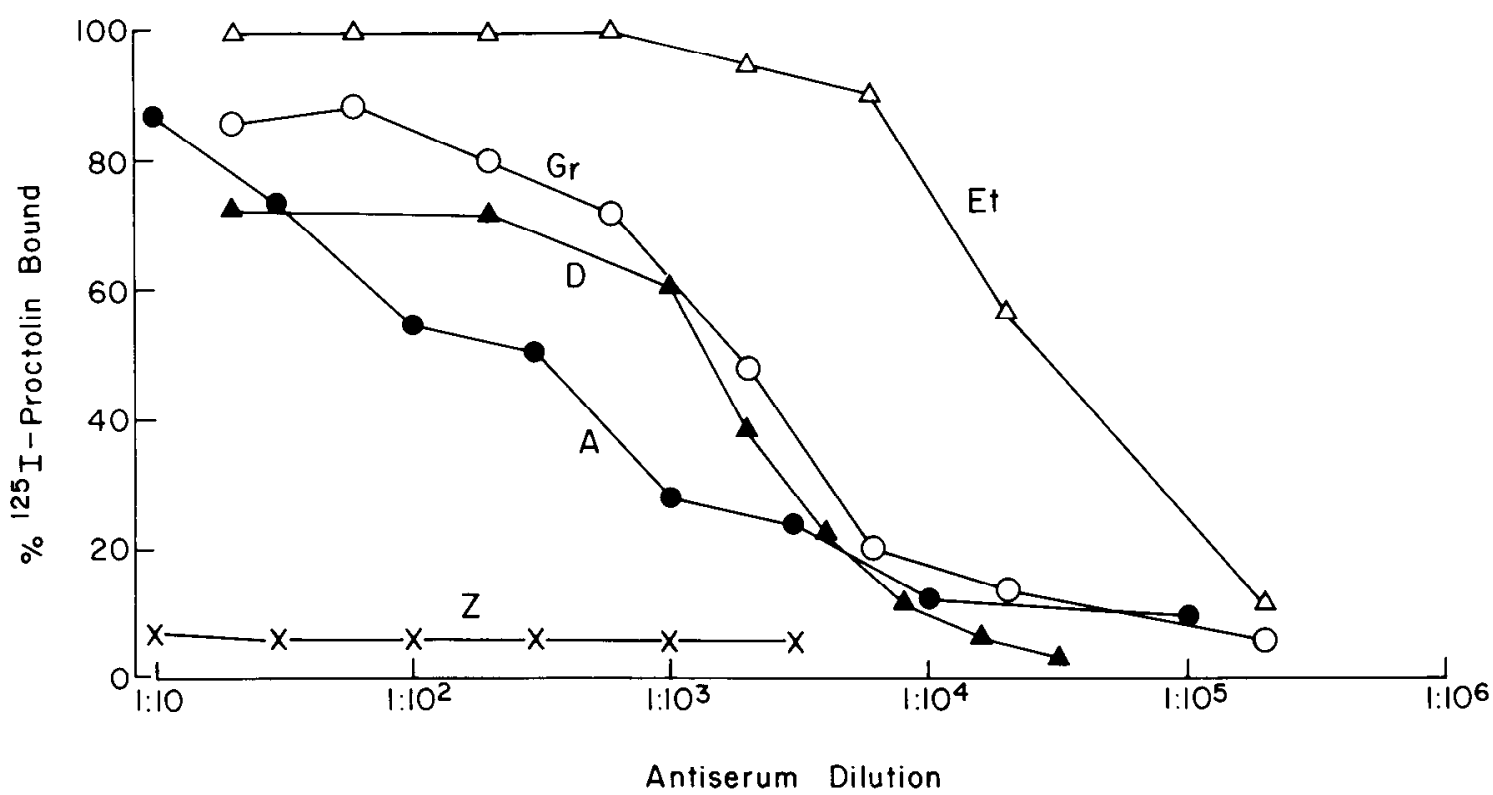

Figure 1. The ability of five sera to bind iodinated proctolin. Dilutions are shown of sera from the four rabbits that produced antibodies to proctolin $(A, D, G r$, and $E t)$ and from one rabbit $(Z)$ that was immunized with the same antigen as rabbit $D$ but failed to produce antibodies to proctolin. The preparation of the antigens and immunization procedures for each serum are described under "Materials and Methods." Each antibody was diluted into an RIA buffer of $0.1 \%$ BSA, $0.2 \%$ sodium azide, and $0.05 \mathrm{M}$ sodium phosphate ( $\mathrm{pH} \mathrm{7.6)}$ and combined with $10,000 \mathrm{cpm}$ of $\left.{ }^{125} \mathrm{I}\right]$ proctolin in a final volume of $200 \mu \mathrm{l}$. After $18 \mathrm{hr}$ at $4^{\circ} \mathrm{C}, 100 \mu \mathrm{l}$ of $2 \%$ dextran-coated charcoal (in $10 \%$ fetal calf serum and $6.6 \mathrm{~mm}$ sodium phosphate, $\mathrm{pH} 7.6$ ) were added, and bound and free proctolin were separated by centrifugation at $2000 \times g$ for $12 \mathrm{~min}$. Antiserum $D$ was used for radioimmunoassays and antiserum $A$ for immunocytochemistry. Antisera $G r$ and $E t$ have not yet been fully characterized.

microliters of $10 \mathrm{mg} / \mathrm{ml}$ 1-ethyl-3-(3-dimethylaminoprolyl) carbodiimide were added to $0.75 \mathrm{ml}$ of water containing $5 \mathrm{mg}$ of proctolin, $42 \mathrm{mg}$ of thyroglobulin, and 20,000 cpm of $\left[{ }^{125} \mathrm{I}\right]$ proctolin. After $18 \mathrm{hr}$ at room temperature, $1 \mathrm{ml}$ of $1 \mathrm{M}$ hydroxylamine was added to the solution. After an additional $5 \mathrm{hr}$ the antigen was dialyzed against 2 liters of distilled water for $48 \mathrm{hr}$. Approximately $60 \%$ of the iodinated tracer was cross-linked to the thyroglobulin. The antigen was used at this concentration (approximately $1.5 \mathrm{mg}$ of conjugated proctolin $/ \mathrm{ml}$ ) for one rabbit and at a 10-fold dilution for the other. For both rabbits, the conjugate was emulsified with an equal volume of Freund's complete adjuvant, and $0.6 \mathrm{ml}$ of the mixture was given every 10 days for five injections. Thereafter, the rabhits received booster injections of the same size every 15 to 20 days.

Radioimmunoassay. Antiserum $D$ was diluted 1:500 into an RIA buffer of $0.1 \%$ BSA, $0.2 \%$ sodium azide, and $0.05 \mathrm{M}$ sodium phosphate ( $\mathrm{pH}$ 7.6). One hundred microliters of the diluted antiserum were combined with $50 \mu \mathrm{l}$ of iodinated proctolin (diluted into the same RIA buffer so as to contain 3,000 to $10,000 \mathrm{cpm} / 50 \mu \mathrm{l}$ ) and $50 \mu \mathrm{l}$ of either a sample or a proctolin standard. After $18 \mathrm{hr}$ at $4^{\circ} \mathrm{C}, 100 \mu \mathrm{l}$ of $2 \%$ dextran-coated charcoal (in $10 \%$ fetal calf serum and $6.6 \mathrm{~mm}$ sodium phosphate, $\mathrm{pH} 7.6$ ) were added and the assay tube was centrifuged at $2000 \times \mathrm{g}$ for 12 min. Two hundred microliters of the supernatant fluid were removed, and both the pellet and the supernatant fractions were counted in a Packard PGD Auto-Gamma Counter.

As little as $10 \mathrm{fmol}$ of proctolin could be detected in this assay, and $70 \mathrm{fmol}$ reduced antibody binding of the iodinated proctolin by $50 \%$. To test the specificity of the assay for proctolin-like compounds, 13 unrelated peptides and amines were added to the assay in the following amounts: $\alpha$-melanocyte-stimulating hormone, $0.9 \mathrm{nmol}$; Leu-enkephalin, $1.1 \mathrm{nmol}$; Met-enkephalin, $17 \mathrm{nmol}$; somatostatin, $0.9 \mathrm{nmol}$; eledoisin, $0.7 \mathrm{nmol}$; eledoisin-related peptide, $0.8 \mathrm{nmol}$; neurotensin, $1.5 \mathrm{nmol}$; oxytocin, $1.0 \mathrm{nmol}$; FMRF-amide, $1.4 \mathrm{nmol}$; physalaemin, $0.7 \mathrm{nmol}$; substance P, $1.2 \mathrm{nmol}$; serotonin, $100 \mathrm{nmol}$; octopamine, 100 nmol. No cross-reactions were observed; thus, the RIA is at least $10^{5}$-fold selective for proctolin over these unrelated compounds. Nevertheless, immunoreactive material that we detect in tissues may not be authentic proctolin and may not be accurately quantified by the assay. Amounts of immunoreactivity are reported as the amount of authentic proctolin necessary to cause equivalent displacement in the RIA.

Samples from experiments on the release of proctolinlike immunoreactivity (see below) contained too much $\mathrm{Ca}^{++}$to assay in a phosphate buffer. For these experiments the buffer described above was replaced with 0.05 M sodium acetate ( $\mathrm{pH} 7.5$ ), and a 2.5-fold higher concentration of the antiserum was used. For assaying HPLC fractions, the strength of the RIA buffer was increased to $0.1 \mathrm{M}$ sodium phosphate.

Tissue extraction. Lobsters (H. americanus) were dissected in physiological saline (Evans et al., 1976a), and each tissue was homogenized in $200 \mu \mathrm{l}$ of methanol:water:acetic acid (90:9:1) (Holman and Cook, 1979a). The sample was transferred to a $1.5-\mathrm{ml}$ microfuge tube, and the homogenizer was rinsed with an additional 100 $\mu \mathrm{l}$ of the homogenization solution. Insoluble material was 
removed by centrifugation for $2 \mathrm{~min}$ at $8000 \times g$ in a Beckman microfuge. The supernatant fluid was withdrawn, and the pellet was re-extracted with $200 \mu$ l of homogenization solution and centrifuged again. The supernatant fractions were combined, dried under nitrogen, and resuspended in $0.5 \mathrm{ml}$ of RIA buffer. $\left[{ }^{125} \mathrm{I}\right]$ Proctolin was added to some tissue samples before homogenization, and the recovery of this tracer was greater than $90 \%$. The protein content of most tissues was also determined (Lowry et al., 1951).

For some tissues with little or no immunoreactive material (the heart, ovaries, and hepatopancreas), it was necessary to assay a large volume of tissue. In such cases, in order to remove salts or other substances that might interfere with the RIA, we partially purified a peptide fraction with a Waters SEP-PAK C18 cartridge. Tissues were homogenized in at least 3 times their volume of $6 \%$ trichloroacetic acid (TCA), and insoluble material was removed as above. The pellet was re-extracted with 300 $\mu \mathrm{l}$ of $6 \% \mathrm{TCA}$, and the pooled supernatants were applied to a Sep-Pak cartridge that had been washed with $5 \mathrm{ml}$ each of acetone, water, and $6 \%$ TCA. Five milliliters of water and $5 \mathrm{ml}$ of $20 \% \mathrm{MeOH}: 0.08 \%$ trifluoroacetic acid were then passed through the cartridge. Finally, proctolin-like material was eluted with $5 \mathrm{ml}$ of $40 \% \mathrm{MeOH}$ : $0.06 \%$ trifluoroacetic acid. The sample was dried under nitrogen and resuspended in RIA buffer. When synthetic proctolin was applied to the cartridge in this manner, greater than $90 \%$ was recovered.

Release experiments. To investigate the release of proctolin-like immunoreactivity, two pericardial organs from the second thoracic segment were dissected and pinned out in a small well of Sylgard (Dow Corning). The pericardial organs were incubated at 12 to $14^{\circ} \mathrm{C}$ in $300 \mu \mathrm{l}$ of saline. At regular intervals, the saline was drawn off with a Pasteur pipette, and $300 \mu \mathrm{l}$ of fresh saline were applied. The pericardial organs could be depolarized with saline in which the concentration of $\mathrm{KCl}$ was increased from $16 \mathrm{~mm}$ to $100 \mathrm{mM}$, with the concentration of $\mathrm{NaCl}$ decreased to maintain constant ionic strength. For calcium-free saline, $\mathrm{CaCl}_{2}$ was replaced with $\mathrm{MgCl}_{2}$. At the end of an experiment, tissues were removed from the well and extracted as described above.

Immunoreactivity in the hemolymph. To look for circulating proctolin-like compounds, $20 \mathrm{ml}$ of hemolymph were drawn from the pericardial sinus into a syringe containing $1.2 \mathrm{ml}$ of $100 \%$ TCA (w/v) and were placed on ice. The hemolymph was transferred to a centrifuge tube, and the precipitate was removed by centrifugation for $30 \mathrm{~min}$ at $6000 \times \mathrm{g}$. The supernatant fluid was desalted on a Sep-Pak C18 cartridge (see "Tissue Extraction," above), and the sample was dried under nitrogen and resuspended in $250 \mu$ l of RIA buffer. Duplicate $100-\mu$ l portions were assayed. The recovery of proctolin was 40 to $60 \%$ in six trials in which $\left[{ }^{3} \mathrm{H}\right]$ proctolin or synthetic proctolin was placed in the syringe before the hemolymph was drawn.

To estimate the half-life of proctolin in hemolymph, $50 \mathrm{pmol}$ of proctolin in $200 \mu \mathrm{l}$ of saline were injected into the ventral sinus to give an approximate concentration of proctolin in the hemolymph of $3 \times 10^{-10} \mathrm{M}$. At intervals thereafter, $1 \mathrm{ml}$ of hemolymph was withdrawn from the pericardial sinus into syringes containing $60 \mu \mathrm{l}$ of $100 \%$ TCA (w/v). Insoluble material was removed by centrifugation for 2 to $3 \mathrm{sec}$ at $8000 \times \mathrm{g}$ in a Beckman microfuge, the pellet was re-extracted with $0.5 \mathrm{ml}$ of $6 \%$ TCA, and the supernatant fractions were processed as described in the preceding paragraph. To take into account the dilution of the injected proctolin in the hemolymph, lobsters were also injected with $1 \mu \mathrm{Ci}$ of $\left[{ }^{14} \mathrm{C}\right]$ inulin. The inulin space was approximately $175 \mathrm{ml}$, and the dilution of inulin into this space was accomplished within $3 \mathrm{~min}$. Thereafter, the concentration of inulin in the hemolymph declined at a much slower rate, with a half-life greater than $1 \mathrm{hr}$.

Immunocytochemistry. Pericardial organs were dissected in ice-cold lobster saline, pinned out in Sylgardcoated Petri dishes, and incubated at $12^{\circ} \mathrm{C}$ for $2 \mathrm{hr}$, during which time they were rinsed several times with fresh saline. They were fixed overnight at $4^{\circ} \mathrm{C}$ in formaldehyde $(4 \%$ paraformaldehyde containing salts in the same concentrations as the saline, buffered at $\mathrm{pH} 7.4$ with $0.2 \mathrm{M}$ cacodylate). The temperature of the fixative was 10 to $15^{\circ} \mathrm{C}$ when it was added to the tissue.

Antibodies that bound nonspecifically to lobster nervous tissue were removed by preabsorbing the antiserum with a homogenized lobster tissue that had been demonstrated by RIA to contain low levels of proctolin-like immunoreactivity (see "Results"). The formaldehydefixed first roots of thoracic ganglia were homogenized in approximately $15 \mathrm{vol}$ of $0.1 \mathrm{M}$ phosphate, $\mathrm{pH} 7.4,0.3 \%$ Triton $\mathrm{X}-100,0.1 \%$ sodium azide. Antiserum $A$ was diluted 1:300 into this homogenate. The mixture was agitated at room temperature for $1 \mathrm{hr}$, then centrifuged at $100,000 \times g$ for $30 \mathrm{~min}$. The supernatant solution was diluted by $10 \%$ with normal goat serum. In experiments testing the specificity of the immunofluorescence, this solution was absorbed with various test substances overnight at $4^{\circ} \mathrm{C}$, then centrifuged at $100,000 \times g$ for $30 \mathrm{~min}$ to precipitate any immune complexes that might have formed.

Fixed pericardial organs were rinsed for 20 to $24 \mathrm{hr}$ with $0.1 \mathrm{M}$ sodium cacodylate, $\mathrm{pH} 7.4$, then for another 4 to $7 \mathrm{hr}$ with $0.1 \mathrm{M}$ phosphate, $\mathrm{pH} 7.4$, containing $0.1 \%$ sodium azide. Tissues were incubated for 1 to $2 \mathrm{hr}$ with $10 \%$ normal goat serum in the phosphate-Triton-azide solution. Then each pericardial organ was transferred into $100 \mu \mathrm{l}$ of the antibody solution and incubated overnight at $4^{\circ} \mathrm{C}$. Samples were rinsed at least six times with $1 \mathrm{ml}$ of phosphate-Triton-azide over 24 to $48 \mathrm{hr}$ and then for 1 to $2 \mathrm{hr}$ in $10 \%$ normal goat serum. Affinity-isolated goat anti-rabbit antibody to which fluorescein isothiocyanate was conjugated (Boehringer-Mannheim) was used as the secondary antibody at a dilution of $1: 20$, with $10 \%$ normal goat serum. After overnight incubation with this antibody at $4^{\circ} \mathrm{C}$, the tissues were rinsed with phosphate-Triton-azide (12 to $18 \mathrm{hr}$ ), then with $0.1 \mathrm{M}$ phosphate, $0.1 \%$ azide ( 4 to $6 \mathrm{hr}$ ), and then for a few seconds with $4 \mathrm{mM} \mathrm{Na}_{2} \mathrm{CO}_{3}$. Finally, tissues were mounted with $80 \%$ glycerol in $20 \mathrm{mM} \mathrm{Na} \mathrm{CO}_{3}$ and allowed to clear for at least $1 \mathrm{hr}$ before viewing.

High pressure liquid chromatography. Reverse phase HPLC was performed on a Waters $\mu$ Bondapak C18 column. The HPLC system was composed of a 6000A pump 
and an M-45 pump controlled by a Model 660 solvent programmer (Waters Associates), an Altex 210 injection valve, a Waters Model 441 UV absorbance detector (214 $\mathrm{nm}$ ), an ISCO Model 1850 fraction collector, and a Perkin-Elmer 023 chart recorder.

Fxtracts for chromatography were made from pericardial organs of 1 to 22 lobsters (see above). The extracts were dried under nitrogen and resuspended in one of two buffers: $2 \mathrm{mM} \mathrm{NaH} \mathrm{NO}_{4}$, pH 5.6, or $0.1 \%$ trifluoroacetic acid.

Two chromatographic separations were used. For the first, the column was equilibrated with $5 \%$ acetonitrile:95\% phosphate buffer ( $\left.2 \mathrm{mM} \mathrm{NaH}_{2} \mathrm{PO}_{4}, \mathrm{pH} 5.6\right)$. A sample was injected in $250 \mu \mathrm{l}$ of phosphate buffer and was eluted with a $90-\mathrm{min}$ gradient of 5 to $50 \%$ acetonitrile at a flow rate of $1 \mathrm{ml} / \mathrm{min}$ (Fig. 2). For the second separation, an isocratic procedure, the column was equilibrated with $20 \%$ methanol: $0.08 \%$ trifluoroacetic acid. A sample was injected in $250 \mu \mathrm{l}$ of $0.1 \%$ trifluoroacetic acid and was eluted with $20 \%$ methanol:0.08\% trifluoroacetic acid at a flow rate of $1 \mathrm{ml} / \mathrm{min}$. Fractions of 1 $\mathrm{ml}$ were collected, dried in a Savant Speed Vac Concentrator, and resuspended in RIA buffer.

In both HPLC systems, when $\left[{ }^{3} \mathrm{H}\right]$ proctolin was injected with synthetic proctolin, the two co-eluted precisely. In some experiments, $\left[{ }^{3} \mathrm{H}\right]$ proctolin was injected with a sample and a portion of each fraction (usually $10 \%$ ) was counted to monitor recovery of the peptide and to mark the fractions in which authentic proctolin eluted. This tracer contained less than 0.1 pmol of proctolin and did not contribute significantly to the immunoreactivity in the pericardial extracts.

Mass spectrometry. Fast atom bombardment mass spectrometry (FABMS) was performed on a double focusing (Varian MAT 731) mass spectrometer of Mattauch-Herzog geometry with a mass range of 1 to 2000 atomic mass units (amu) at $8 \mathrm{kV}$ accelerating potential. The optimization of the probe, the ionization by a Xe neutral beam, and the general operating procedures for peptide analysis were as described by Martin et al. (1982). Exact mass measurements were made at a resolution of $1: 10,000$. Samples, either synthetic proctolin or the proctolin-like peptide purified from lobster tissue, were collected from the HPLC directly into cleaned 1-ml Reactivials (Pierce) and were dried under nitrogen. Samples were dissolved in $100 \mu \mathrm{l}$ of water, dried under vacuum in a Speed Vac concentrator, and redissolved in $1 \mu$ l of $20 \%$ acetic acid. Approximately $2 \mu \mathrm{l}$ of glycerol were added to the samples, and approximately $0.5 \mu \mathrm{l}$ of the acidified sample-glycerol mixture was applied to the probe for the analysis.

\section{Results}

Distribution of proctolin-like immunoreactivity. The central nervous system of the lobster is a chain of 15 ganglia joined by connectives. The brain is the largest and most anterior of these ganglia, and it is followed by a pair of circumesophageal ganglia, the subesophageal ganglion, five thoracic ganglia, and six abdominal ganglia. The thoracic ganglia and the first five abdominal ganglia connect with peripheral structures in their par- ticular segment through a regular pattern of nerve roots. From each side of a thoracic ganglion a large nerve root emerges which contains most of the sensory and motor innervation of the somite and appendage of that segment. A thinner more posterior pair of nerve roots is also associated with each thoracic ganglion, and these second roots innervate thoracic extensions of abdominal muscles. Near the nerve cord, the second roots are covered with neurosecretory endings (Evans et al., 1976a, b; Livingstone et al., 1981; Beltz and Kravitz, 1983). A lateral branch of this root extends out to the pericardial organs, which appear as blue-white enlargements of the nerve stretched across the openings of the branchiocardiac veins. They are most highly developed in the first three thoracic segments. From each of the first five abdominal ganglia, three roots emerge on each side. The most anterior pair, the first roots, innervate swimmerets; the second roots go to extensor muscles; and the third roots innervate flexor muscles of the abdomen.

To survey the distribution of proctolin-like immunoreactivity, the nerve cord was dissected and divided so that each ganglion and the connectives that link the ganglia could be assayed separately. Of the first roots of each thoracic segment, a 3- to 5-mm piece was assayed, and a similar length was taken for each of the three abdominal roots. The second thoracic roots were dissected more extensively and were divided into three regions: (1) the regions proximal to the ganglion, including the neurosecretory regions; (2) the distal portions of the lateral branches of second roots which extend to the pericardial organs; and (3) the pericardial organs themselves. The protein content of the assayed tissue was determined so that immunoreactivity could be normalized to the size of the structure.

Proctolin-like immunoreactivity is detectable in nearly every portion of the lobster nervous system (Table I). Each ganglion contains 0.5 to 4.0 pmol of immunoreactivity; the largest ganglia (the brain and subesophageal) have higher levels than thoracic ganglia, and these, in turn, have somewhat higher levels than the abdominal ganglia. Even when normalized to the protein content of the tissue, the amount of proctolin-like material tends to be greater in the anterior ganglia. Significant amounts $(0.2$ to $1.0 \mathrm{pmol})$ are also present in connectives between ganglia.

By far the largest amount of immunoreactivity is found in the pericardial organs; a pair of pericardial organs (from the left and right sides of a thoracic segment) contains in the range of 2 to $20 \mathrm{pmol}$. Together, the pericardial organs of the first three thoracic segments account for approximately $40 \%$ of the total immunoreactivity we found in the tissues assayed. When the amount of proctolin-like material is normalized to the amount of protein in the tissue, the pericardial organs, which are relatively small structures, are about 100 -fold enriched over larger tissues, like the brain.

Other regions with exceptionally high concentrations of immunoreactivity are the proximal portions of the second roots of the subesophageal and first four thoracic ganglia. Although the amounts of proctolin-like material they contain (0.7 to $1.4 \mathrm{pmol}$ per pair of roots) are not comparable to those of the pericardial organs, they are, 
TABLE I

Proctolin-like immunoreactivity

Proctolin-like immunoreactivity is detectable in nearly every portion of the nervous system of $H$. americanus. The nervous system was dissected, subdivided, extracted, and assayed as described under "Materials and Methods" and "Results." The values for nerve roots and pericardial organs are for pairs of tissue samples taken from the left and right sides of the particular segment. A large variability was encountered in the values for some tissues. This may reflect differences from animal to animal or variability in the dissections. For completeness, some tissues are included for which only a single determination is available. However, these values are always in good agreement with the values obtained for the corresponding structures in other segments of the lobster. For tissues where two or fewer values of picomoles are available, the individual values are shown. For the normalized values in the right column, the variability is expressed as range where $N=2$, and as standard deviation where $N>2$ (indicated by asterisks).

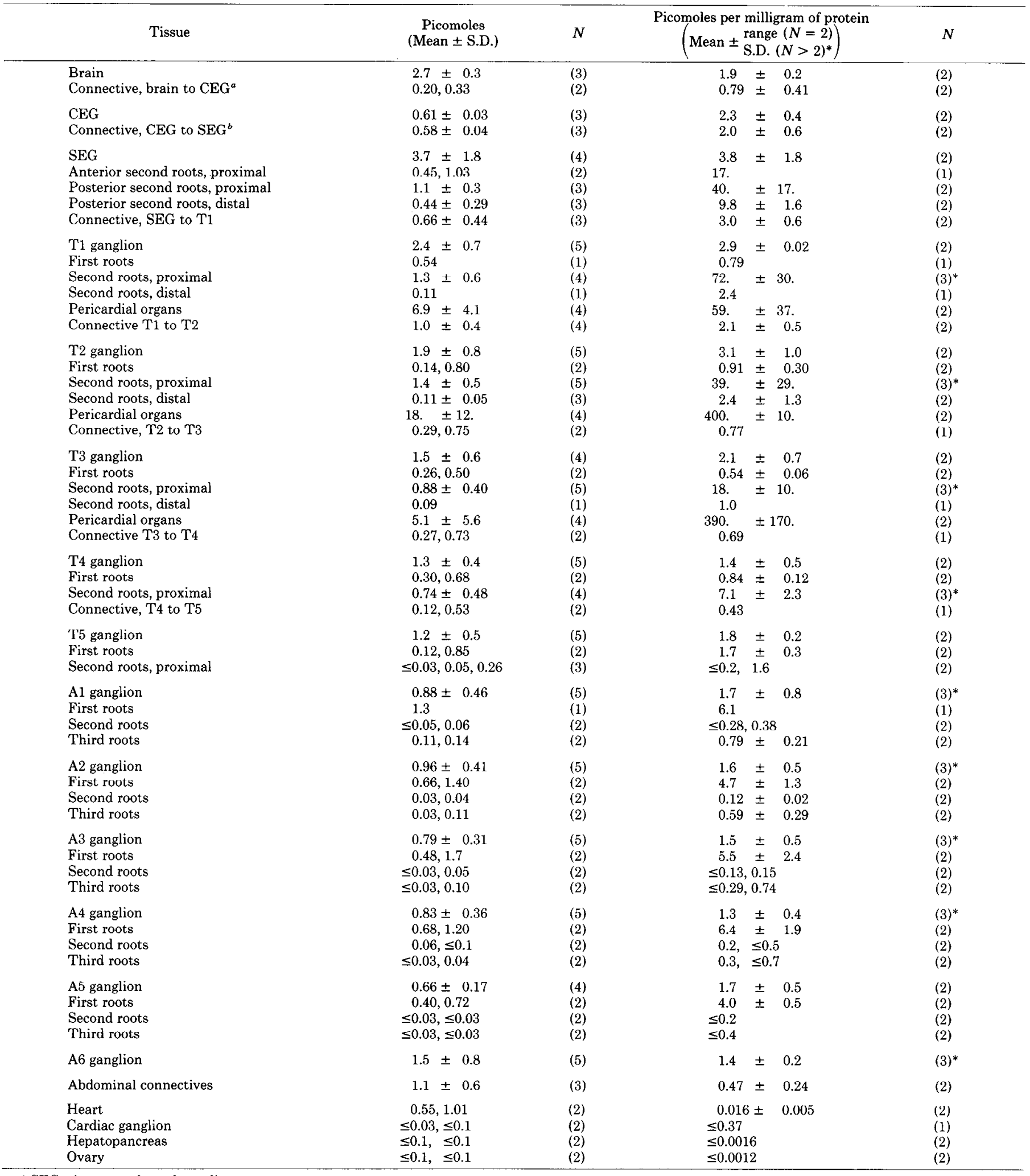

"CEG, circumesophageal ganglion.

${ }^{\circ} \mathrm{SEG}$, subesophageal ganglion. 
in this survey, second only to the pericardial organs in immunoreactivity per milligram of protein and are 10 to 20 -fold enriched over the first thoracic roots or the distal portions of the second thoracic roots. Like the pericardial organs, these neurosecretory sites are also rich in serotonin and octopamine (Evans et al., 1976a; Livingstone et al., 1981; Beltz and Kravitz, 1983). The eyestalk also contains neurosecretory cells and endings (Welsh, 1960; Kleinholz, 1976). When this structure was assayed together with the optic nerve, appreciable immunoreactive material $(2.84 \pm 1.64 \mathrm{pmol})$ was detected.

Some regions of the nervous system have very little proctolin-like material. The second and third roots of the abdominal ganglia, for example, contain barely detectable levels, although the first abdominal roots (the nerves for the swimmerets) contain significant amounts. Similarly, no immunoreactivity was measured in the cardiac ganglion, which lies within the heart. The heart itself, however, with the ganglion removed, contains 0.8 \pm 0.4 pmol.

Chemical characterization of proctolin-like immunoreactivity. Because our survey of lobster tissues indicated that the pericardial organs have the highest content of proctolin-like material, subsequent studies focused on these neurosecretory structures. In particular, the pericardial organs were used as a source of immunoreactive material for the chemical characterization of lobster proctolin.

The proctolin-like material in pericardial organ extracts was compared with synthetic proctolin in two HPLC systems and by fast atom bombardment mass spectrometry. The first chromatographic separation is illustrated in Figure 2, the fractionation of an extract of eight pericardial organs from two lobsters. Immunoreactivity was detected in fractions 59 to 61 . $\left[{ }^{3} \mathrm{H}\right]$ Proctolin, which had been added as a tracer, eluted in the same fractions, and no immunoreactivity could be detected in any other fractions. In this system, the recovery of $\left[{ }^{3} \mathrm{H}\right]$ proctolin was 90 to $95 \%$, and the recovery of immunoreactivity from lobster extracts ranged from 77 to $100 \%$. Because the RIA could compare the immunoreactivity in two samples with an accuracy of only $20 \%$, we do not know whether a small amount of immunoreactive material remained bound to the column. In the experiment shown in Figure 2, the proctolin-like material $(16 \mathrm{pmol})$ was less than the amount necessary for detection by the UV absorbance monitor. However, the absorbance record demonstrates that this chromatographic system, by retaining the peptide for $59 \mathrm{~min}$, separates it from a vast excess of more polar UV-absorbing compounds.

A second chromatographic system (Fig. 3) was used in which the pattern of elution of peptides is very different from that of the first system. In the first, for example, leucine-enkephalin elutes just before proctolin (fractions 57 and 58), whereas in the second system leucine-enkephalin is retained for more than 4 times as long as proctolin (fractions 65 to 70 versus fractions 14 to 16 ). In Figure 3,29 pmol of immunoreactivity from four pericardial organs of a single lobster were injected with a tracer of $\left[{ }^{3} \mathrm{H}\right]$ proctolin. As in the first system, the proctolin-like material eluted as a single peak that comigrated precisely with authentic proctolin. The recovery of immunoreactivity was $85 \%$.

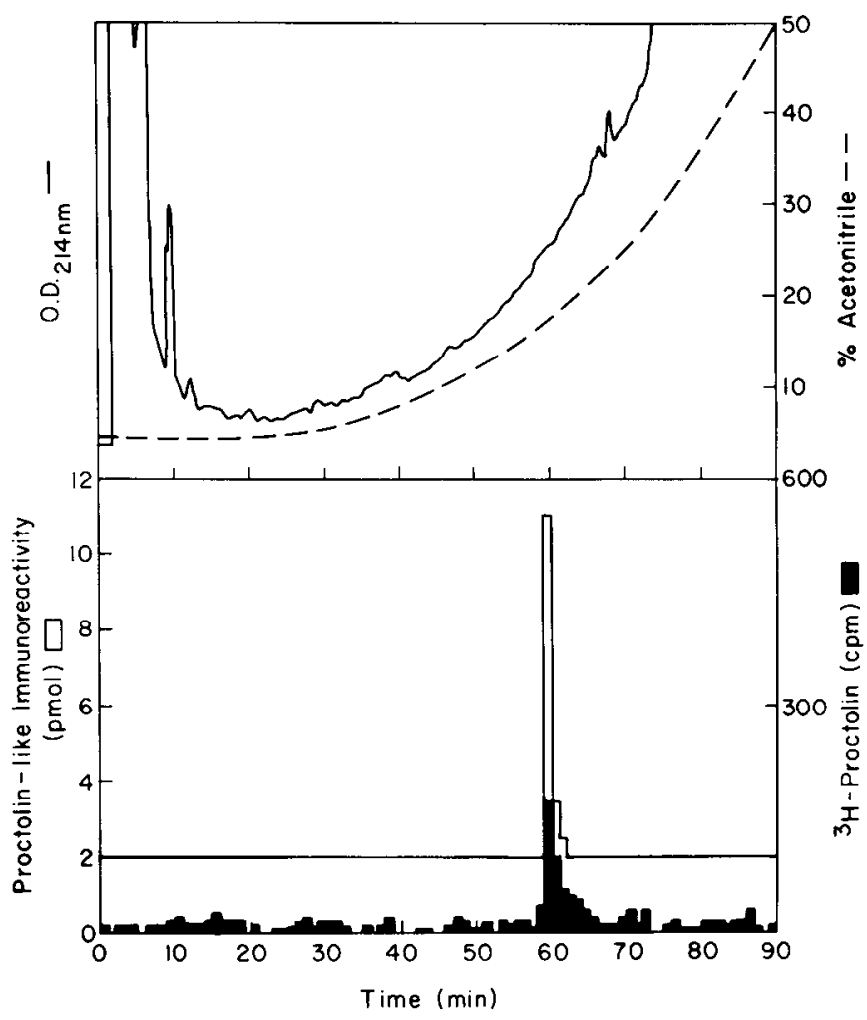

Figure 2. Proctolin-like material from lobster pericardial organs and authentic proctolin co-elute in reverse phase HPLC. $\left[{ }^{3} \mathrm{H}\right]$ Proctolin $(3500 \mathrm{cpm}$, approximately $0.1 \mathrm{pmol}$ ) was added to an extract of eight pericardial organs from two lobsters (see "Materials and Methods") and applied to a C18 column equilibrated with $5 \%$ acetonitrile:95\% $2 \mathrm{mM} \mathrm{NaH}_{2} \mathrm{PO}_{4}, \mathrm{pH}$ 5.6. Material was eluted by a gradient of acetonitrile that is indicated by the broken line in the upper half of the figure. The flow rate was $1 \mathrm{ml} / \mathrm{min}$, and the absorbance of the eluant at $214 \mathrm{~nm}$ was monitored continuously (solid line). The slow increase in absorbance is due to the changing solvent composition. The amount of proctolin-like material in the sample (16 pmol) is below the limit of detection of the UV monitor (approximately $30 \mathrm{pmol}$ ). Fractions of $1 \mathrm{ml}$ were collected. The retention time of authentic proctolin is indicated by the solid bars, which represent the amount of ${ }^{3} \mathrm{H}$ in $100 \mu \mathrm{l}$ of each fraction. One percent of each fraction was used in the RIA, and the amount of immunoreactivity in each fraction is indicated by the open bars. The limit of detection in this experiment was $2 \mathrm{pmol} /$ fraction. In similar experiments, up to $200 \mathrm{pmol}$ of immunoreactivity from 32 pericardial organs were analyzed, and a larger portion of each fraction $(50 \%)$ was assayed in order to look for additional peaks of immunoreactivity, but none were observed.

For mass spectrometry 120 pericardial organs from 22 lobsters were extracted with $2 \mathrm{ml}$ of $6 \%$ TCA. An initial purification was performed on a Sep-Pak cartridge (see "Materials and Methods"), and the proctolin-like material was then isolated by the sequential use of the two HPLC systems described above. Five hundred picomoles of the purified immunoreactive material were obtained for the spectrometry, and an equal amount of synthetic proctolin was purified by HPLC for comparison.

The mass spectra of the lobster peptide and synthetic proctolin both show a major peak at $m / z=649$, which corresponds to the molecular protonated ion of proctolin, (proctolin $+\mathrm{H})^{+}$. This region of the mass spectra is 


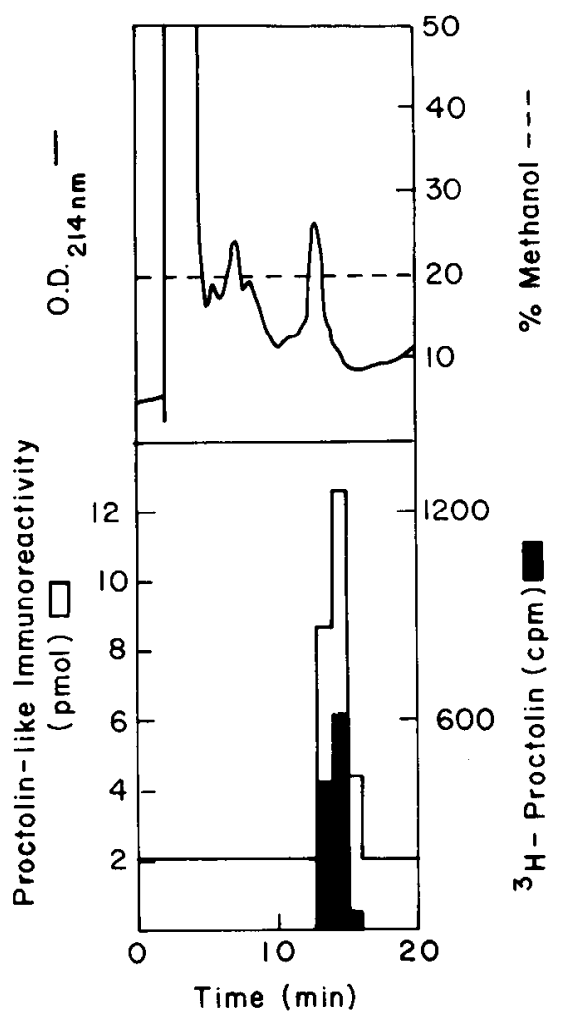

Figure 3. Authentic proctolin and immunoreactivity from pericardial organs co-elute in a second HPLC system. Twentynine picomoles of immunoreactivity in an extract of four pericardial organs from a single lobster was combined with 10,000 cpm of $\left[{ }^{3} \mathrm{H}\right]$ proctolin $(0.1 \mathrm{pmol})$ and applied to a $\mathrm{C} 18$ column. Material was eluted from the column with $20 \%$ methanol: $0.08 \%$ trifluoroacetic acid at a flow rate of $1 \mathrm{ml} / \mathrm{min}$, and $1-\mathrm{ml}$ fractions were collected. The proctolin-like peptide was not visible in the record of UV absorbance (solid line) but was detected by radioimmunoassay of $1 \%$ of each fraction (open bars indicate picomoles of immunoreactivity per fraction; 2 $\mathrm{pmol} /$ fraction is the limit of detection in this experiment). The retention time of authentic proctolin is indicated by the solid bars (counts per minute of $\left.{ }^{3} \mathrm{H}\right]$ proctolin in $100 \mu \mathrm{l}$ of each fraction).

shown in Figure 4. The glycerol matrix in which the samples were dissolved provides a reference peak at $\mathrm{m} / z$ $=645$, which corresponds to the molecular protonated ion of an oligomer of seven glycerol molecules, $\left(\mathrm{G}_{7}+\mathrm{H}\right)^{+}$ (Martin et al., 1982). Using the precise mass of $\left(\mathrm{G}_{7}+\right.$ $\mathrm{H})^{+}$as a reference $(m=645.3392)$, the precise mass of the protonated lobster peptide was determined by peak matching to be 649.3655 amu and that of protonated synthetic proctolin was $649.3666 \mathrm{amu}$. These experimental values agree well with each other and with the expected mass of protonated proctolin, calculated from its molecular formula, $\mathrm{C}_{30} \mathrm{H}_{49} \mathrm{~N}_{8} \mathrm{O}_{8}$, to be 649.3673 .

Since fast atom bombardment produces relatively little fragmentation of small peptides, no fragments of proctolin were detectable above background, and, more detailed structural information could not be gleaned from the spectra. We cannot exclude the possibilities that, in lobster proctolin, isoleucine is substituted for leucine or that a permutation of the sequence of amino acids has occurred, since these changes would not alter the precise mass of the molecular ion. Yet, the ability of the RIA to recognize the peptide and the inability of two HPLC systems and mass spectrometry to distinguish the isolated material from synthetic proctolin strongly suggests that lobster pericardial organs contain authentic proctolin.

Immunocytochemistry. Since the highest concentrations of immunoreactivity are found in the pericardial organs, and because this material has been characterized chemically (see above), we began our immunocytochemical studies with these tissues. Staining for proctolin-like immunoreactivity reveals a dense network of fine varicose processes covering the surface of each pericardial organ and continuing in the thin sheet which fans out from the nerve trunk to nearby muscles (Fig. 5). The second nerve roots from the first through third thoracic ganglia each contain one or two axons that show proctolin-like immunofluorescence. Varicosities begin to appear on the surface of the nerve trunk very abruptly, at the point where the nerve crosses the branchiocardiac vein and enlarges into the pericardial organ. At the same point, second roots intersect a small connective nerve that runs between pericardial organs and contains many (up to 17) immunofluorescent axons. The cell bodies that give rise to these axons have not yet been found. No cell bodies showing proctolin-like immunofluorescence were seen in the area of the pericardial organs.

The specificity of the immunofluorescence for proctolin was tested by preabsorbing the antiserum at its working dilution with the following substances (see "Materials and Methods"): proctolin $(50 \mu \mathrm{g} / \mathrm{ml})$; glutaraldehydecoupled proctolin-BSA conjugate (equivalent to $0.7 \mu \mathrm{g} /$ $\mathrm{ml}$ of proctolin and $2.6 \mu \mathrm{g} / \mathrm{ml}$ of BSA); formaldehydecoupled octopamine-BSA conjugate $(2.6 \mu \mathrm{g} / \mathrm{ml}$ of BSA
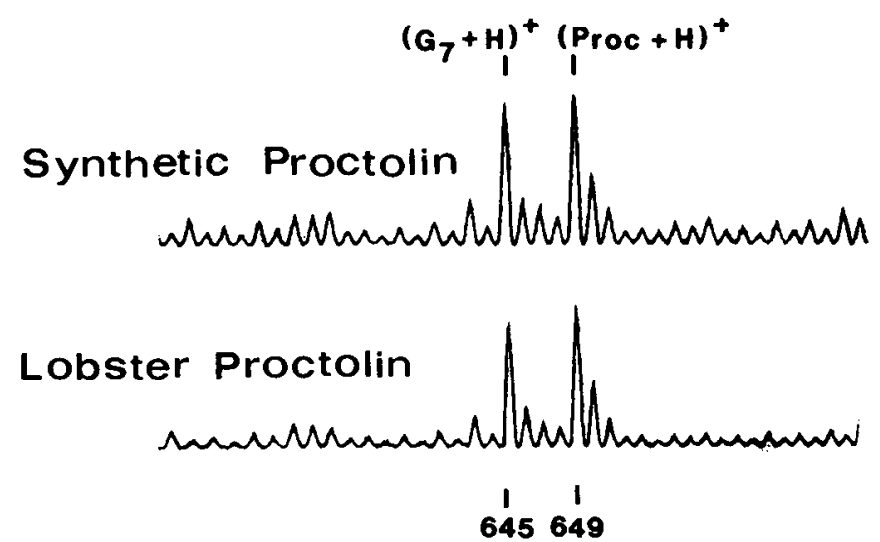

Figure 4. Portions of the mass spectra of lobster proctolin and synthetic proctolin that contain the molecular protonated ion of prectolin. Five hundred picomoles of immunoreactive peptide were isolated from an extract of 120 pericardial organs from 22 lobsters by the use of a Sep-Pak C18 cartridge and the sequential use of the two HPLC systems shown in Figures 2 and 3. An equal amount of synthetic proctolin was similarly purified for comparison. Fast atom bombardment mass spectrometry was performed as described under "Materials and Methods." A reference peak at $\mathrm{m} / z=645$ is formed by the molecular protonated ion of an oligomer of seven glycerol molecules $\left(G_{7}+H\right)^{+}$. The molecular protonated ion of proctolin $(P r o c+I I)^{+}$has a nominal mass of $649 \mathrm{amu}$ and is found in the spectra of both the lobster and the synthetic peptide. 

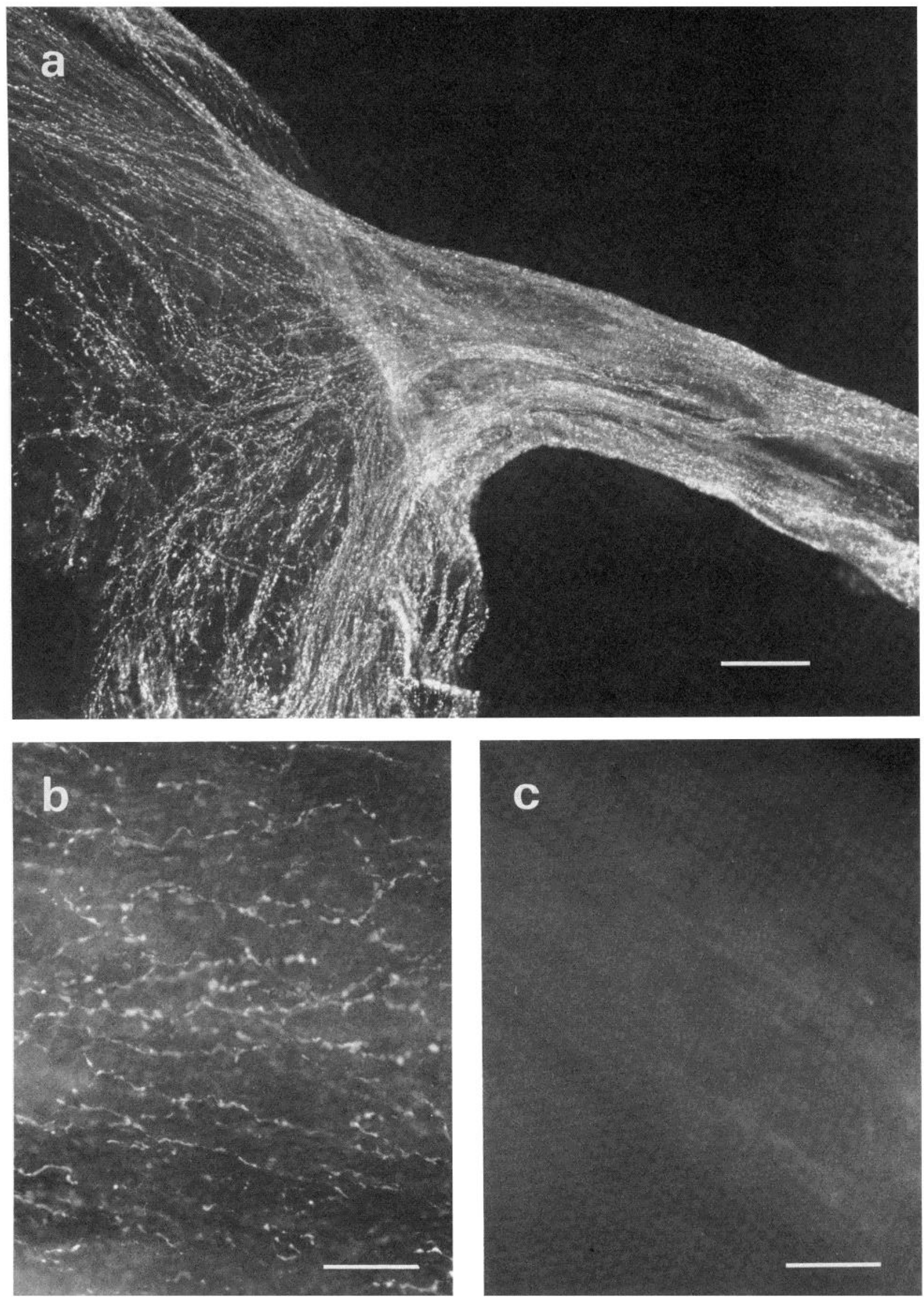

Figure 5. Whole mount immunocytochemical preparations of pericardial organs. $a$, Proctolin-like immunoreactivity is localized in varicose processes on the surface of a first thoracic pericardial organ and throughout the thin sheet which fans out to nearby muscle. Calibration bar $=200 \mu \mathrm{m}$. $b$, A second thoracic pericardial organ that was incubated in primary antibody that had been preabsorbed with BSA $(25 \mu \mathrm{g} / \mathrm{ml})$. Immunoreactive processes are seen on its surface. Calibration bar $=50 \mu \mathrm{m}$. $c$, The second thoracic pericardial organ that was contralateral to that shown in $b$ was incubated in primary antibody that had been preabsorbed with a proctolin-BSA conjugate $(7 \mu \mathrm{g} / \mathrm{ml}$ of proctolin and $25 \mu \mathrm{g} / \mathrm{ml}$ of BSA). No immunoreactivity is seen. A 10 -fold lower concentration of the conjugate was equally effective in blocking the staining. Calibration bar $=50 \mu \mathrm{m}$. 
and $0.2 \mu \mathrm{g} / \mathrm{ml}$ of octopamine); BSA (2.6 $\mu \mathrm{g} / \mathrm{ml}) ; \mathrm{FMRF}$ amide $(100 \mu \mathrm{g} / \mathrm{ml})$; leucine-enkephalin $(56 \mu \mathrm{g} / \mathrm{ml})$; substance $\mathrm{P}(135 \mu \mathrm{g} / \mathrm{ml})$; octopamine $(190 \mu \mathrm{g} / \mathrm{ml})$; and serotonin $(390 \mu \mathrm{g} / \mathrm{ml})$. Of these substances, only free proctolin and the proctolin-BSA conjugate blocked the staining (Fig. 5). Relative to the proctolin-BSA conjugate, much higher concentrations of free proctolin were required to block the immunofluorescence. This may be related to differences in their capacities to form precipitable immune complexes. Alternatively, there may be some antibodies in the serum that have a significantly greater affinity for aldehyde-fixed proctolin than for the free peptide.

Release of proctolin-like immunoreactivity. The abundant network of proctolin-immunoreactive varicosities in the pericardial organs suggests that proctolin may be released from nerve terminals in this tissue. To test this possibility, pairs of pericardial organs were incubated in vitro, and the release of proctolin-like immunoreactivity into the bathing saline was monitored (Fig. 6). During the initial $40 \mathrm{~min}$ of the incubation, large amounts of immunoreactivity were released, possibly because these fragile tissues had been damaged during their dissection, but the amount released gradually declined. Once a steady base line was established, the release of proctolinlike material could be greatly increased by depolarizing the tissue with high $\mathrm{K}^{+}$saline (Fig. 6). The amounts released varied widely from experiment to experiment, probably because of variations in the amounts of the peptide contained in each tissue and in the extent of the damage inflicted by the dissections. In 14 of 17 experiments, large increases in the rate of release were observed: tissues released $21.5 \pm 17.2 \mathrm{fmol} / \mathrm{min}$ (mean \pm

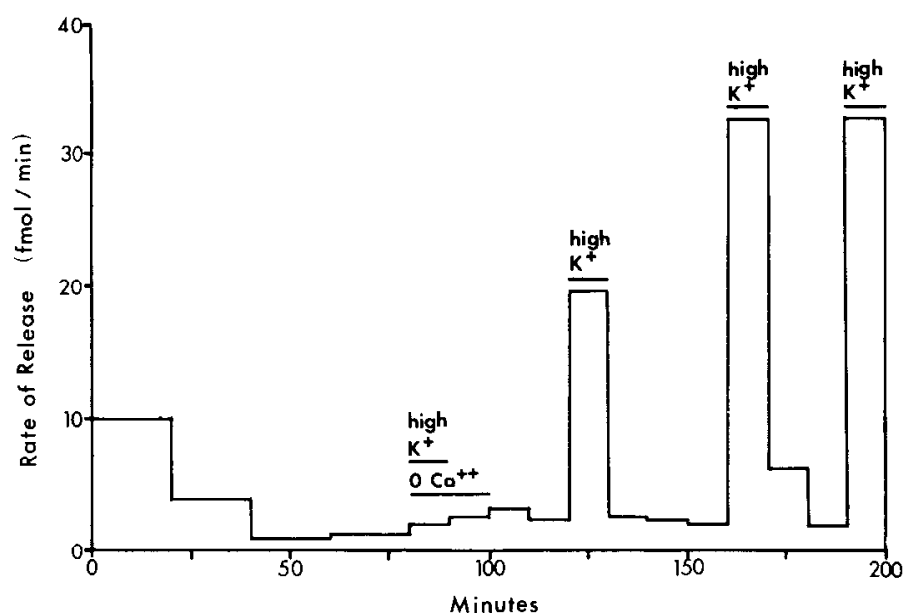

Figure 6. Calcium-dependent release of proctolin-like immunoreactivity in response to depolarization of pericardial organs. Two pericardial organs from the second thoracic segment of a lobster were incubated in $0.3 \mathrm{ml}$ of saline. Saline was replaced at 20 -min intervals for the first $60 \mathrm{~min}$ and at 10 -min intervals thereafter. RIA detected a steady base line of proctolin-like material released into the saline. In the presence of calcium, release was greatly stimulated by depolarization with $100 \mathrm{~mm} \mathrm{~K}^{+}$. At the end of the experiment, the pericardial organs were removed from the well, extracted, and found to contain $22 \mathrm{pmol}$ of proctolin-like immunoreactivity.
SD) when depolarized. In these experiments the pericardial organs contained $18.2 \pm 7.2 \mathrm{pmol}$ of immunoreactivity and thus were releasing approximately $1 \%$ of their stores during a $10-\mathrm{min}$ depolarization. In the three experiments where little or no stimulation of release was detected, only small amounts of the peptide were found in the tissues $(<8 \mathrm{pmol})$.

In the absence of $\mathrm{Ca}^{++}$, high $\mathrm{K}^{+}$consistently failed to cause release. In four experiments like that shown in Figure 6, the first depolarization was in $\mathrm{Ca}^{++}$-free saline, and subsequently the tissue was depolarized in the presence of $\mathrm{Ca}^{++}$. For two other preparations, a trial in the presence of $\mathrm{Ca}^{++}$preceded the depolarization in the absence of $\mathrm{Ca}^{++}$. The order was not significant. All six preparations released immunoreactivity in response to depolarization in the presence of $\mathrm{Ca}^{++}$, and none was stimulated to release in its absence.

Proctolin-like immunoreactivity in the hemolymph. Because pericardial organs can release proctolin-like material and because immunocytochemistry suggests that this material is released into the surrounding hemolymph, we looked for the peptide in the circulation. In hemolymph from four lobsters, however, no immunoreactivity was detected; circulating levels in each animal must have been below $4 \times 10^{-12} \mathrm{M}$. In control experiments, synthetic proctolin was either added to the syringe or injected into a lobster before the hemolymph was drawn so as to give a concentration of $1.5 \times 10^{-11} \mathrm{M}$ in the hemolymph. This proctolin was detectable in the assay, and thus our failure to detect proctolin-like material in the circulation was not due to the rapid destruction of proctolin during processing of the samples. In two preliminary experiments undertaken to estimate the rate of degradation of the peptide in the hemolymph, the halflife of proctolin injected into lobsters was 6 to $10 \mathrm{~min}$.

\section{Discussion}

Proctolin-like immunoreactivity is present in almost every portion of the lobster nervous system. The highest concentrations were found in the pericardial organs, and the immunoreactive material in this tissue is very likely to be authentic proctolin. The material comigrated with synthetic proctolin in two HPLC systems, and after purification it was indistinguishable from synthetic proctolin in fast atom bombardment mass spectrometry. A similar analysis will be necessary to determine if other tissues, such as the central nervous system, contain authentic proctolin.

Many neuropeptides arise from larger precursors (Gainer, 1982; Herbert et al., 1982; Udenfriend, 1982). Although we did not find any proctolin-like immunoreactivity other than the pentapeptide in chromatographic separations of pericardial organs, a proctolincontaining precursor could, nonetheless, have gone undetected. For example, such a molecule might not have been extracted from the tissue by our homogenization solution or might only be present in neuronal cell bodies, which are not present in the pericardial organs. Furthermore, the antiserum may not recognize the proctolin sequence if the terminal residues are not free. Finally, if a precursor represented a small percentage of the extractable immunoreactivity ( $10 \%$ or less) and this material 
failed to elute from the HPLC column, its absence would not have been detected.

What is the role of proctolin in the lobster? Three lines of evidence suggest that the peptide is a neurohormone. (1) Large amounts of the peptide are found in neurosecretory regions-the pericardial organs and the proximal portions of the second thoracic roots. Proctolinlike material in the eyestalk and optic nerve may represent another store for hormonal release. (2) The surface of the pericardial organs is rich in immunoreactive nerve endings, as would be expected if this tissue releases proctolin into the hemolymph. Electron microscopy of Brachyuran pericardial organs (Maynard and Maynard, 1962), of the ligmental plexus in Panulirus, a region analogous to the pericardial organs (Sullivan et al., 1977), and of the proximal region of the second thoracic roots in Homarus (Livingstone et al., 1981) has demonstrated several classes of nerve endings filled with large, densecored vesicles of the sort associated with peptide-containing neurons (Goldsmith, 1977). We expect that these endings include the proctolinergic terminals. These ultrastructural studies also suggest that the endings release material directly into the circulation because no postsynaptic targets were seen; nerve terminals were surrounded by connective tissue and were within microns of the surface of the organ. (3) Depolarizing the pericardial organs in the presence of $\mathrm{Ca}^{++}$releases proctolin-like immunoreactivity into the solution bathing them.

However, to be confident that proctolin actually serves as a neurohormone in the lobster, one must detect the peptide in the circulation at a concentration that is effective on target tissues. The lowest threshold for an effect of proctolin in a crustacean tissue is $10^{-10} \mathrm{M}$ on the dactyl opener muscle of the walking leg (Schwarz et al., 1980). Other crustacean tissues respond to proctolin in the range of $10^{-8}$ to $10^{-7} \mathrm{M}$ (Lingle, 1979; Miller and Sullivan, 1981). In the experiments reported above, however, we did not detect proctolin-like immunoreactivity in the hemolymph in an assay that would have detected levels as low as $4 \times 10^{-12} \mathrm{M}$. Therefore, it is unlikely that peripheral tissues are constantly modulated by circulating proctolin. Possibly, proctolin is released into the circulation only at particular times, such as during fighting, eating, or molting, or in response to trauma. The approximate half-life of proctolin in the hemolymph $(6$ to $10 \mathrm{~min}$ ) suggests that it may only circulate for a brief period.

Can the lobster raise the level of proctolin-like immunoreactivity in the hemolymph to a level effective on target tissues? Together, all the regions of the nervous system that are reported in Table I contain approximately $70 \mathrm{pmol}$. For the concentration to reach $10^{-10} \mathrm{M}$ in the hemolymph (a 175-ml volume, see "Materials and Methods"), one-fourth of all the immunoreactive material would have to be released. This seems particularly unlikely since pericardial organs depolarized in vitro released only $1 \%$ of their contents in a $10-\mathrm{min}$ period. To reconcile this shortage of immunoreactivity with the evidence for a hormonal role, the following five possibilities can be suggested: (1) there may be additional release sites in tissues that were omitted from our survey; (2) there may be reserves of the hormone, perhaps in the form of a precursor, that were not extracted from tissues or detected by the assay; (3) a period of synthesis of proctolin may augment the supply at appropriate times, e.g., prior to molting; (4) the circulating proctolin may act only on tissues near the pericardial organs, such as the heart, thoracic muscles, or other terminals in the pericardial organs, since these tissues would encounter high concentrations of the peptide before it was diluted into the general circulation; (5) proctolin may have actions that are as yet unknown but are evoked by concentrations below $10^{-10} \mathrm{M}$.

Proctolin-like peptides probably serve in nonhormonal capacities as well. In the cockroach, proctolin is found in an identified motoneuron (O'Shea and Bishop, 1982) and is released from terminals in the target muscle where it appears to cause slow, sustained contractions (Adams and O'Shea, 1983). In the lobster, proctolinergic motoneurons may also exist. For example, the low concentration of immunoreactivity in the heart suggests that the heart may receive a direct proctolinergic innervation in addition to being exposed to material released from the pericardial organs. Similarly, immunoreactivity in the first thoracic and first abdominal roots suggests that proctolinergic neurons may innervate peripheral targets of these roots, such as the swimmerets.

In general, the distribution of proctolin is similar to that of the amines, serotonin and octopamine. The highest concentrations of all three occur in the pericardial organs and proximal portions of the second thoracic roots (Evans et al., 1976a; Livingstone et al., 1981). Furthermore, like proctolin, the amines are found at lower levels in every ganglion and connective. 'To learn if there is any connection between the peptide and the amines and to uncover the function of the proctolin-like material throughout the nervous system, it will be necessary to continue these biochemical and histochemical experiments. The localization of immunoreactive material to individual cells should permit physiological studies of identified proctolinergic neurons and their synapses.

\section{References}

Adams, M. E., and M. O'Shea (1983) Peptide co-transmitter at a neuromuscular junction. Science 221: 286-289.

Alexandrowicz, J. S. (1953) Nervous organs in the pericardial cavity of the decapod Crustacea. J. Marine Biol. Assoc. U. K. 32: 175-192.

Belamarich, F. A., and R. Terwilliger (1966) Isolation and identification of cardio-exitor hormone from the pericardial organs of Cancer borealis. Am. Zool. 6: 101-106.

Beltz, B. S., and E. A. Kravitz (1983) Mapping of serotoninlike immunoreactivity in the lobster nervous system. J. Neurosci. 3: 585-602.

Berlind, A., and I. M. Cooke (1970) Release of a neurosecretory hormone as peptide by electrical stimulation of crab pericardial organs. J. Exp. Biol. 53: 679-686.

Bishop, C. A., and M. O'Shea (1982) Neuropeptide proctolin (H-Arg-Tyr-Leu-Pro-Thr-OH): Immunocytochemical mapping of neurons in the central nervous system of the cockroach. J. Comp. Neurol. 207: 223-238.

Bishop, C. A., M. O'Shea, and R. J. Miller (1981) Neuropeptide proctolin (H-Arg-Tyr-Leu-Pro-Thr-OH): Immunological detection and neuronal localization in insect central nervous system. Proc. Natl. Acad. Sci. U. S. A. 78: 5899-5902. 
Brown, B. E. (1975) Proctolin: A peptide transmitter candidate in insects. Life Sci. 17: 1241-1252.

Brown, B. E. (1977) Occurrence of proctolin in six orders of insects. J. Insect. Physiol. 23: 861-864.

Brown, B. E., and A. N. Starratt (1975) Isolation of proctolin, a myotropic peptide, from Periplaneta americana. J. Insect Physiol. 21: 1879-1881.

Cook, B. J., and S. Meola (1978) The oviduct musculature of the horsefly, Tabanus sulcifrous, and its response to 5-hydroxytryptamine and proctolin. Physiol. Entomol. 3: 273280.

Cooke, I. M., and M. W. Goldstone (1970) Fluorescence localization of monoamines in crab neurosecretory structures. J. Exp. Biol. 53: 651-668.

Eckert, M., H. Agricola, and H. Penzlin (1981) Immunocytochemical identification of proctolin-like immunoreactivity in the terminal ganglion and hind gut of the cockroach Periplaneta americana. Cell Tissue Res. 217: 633-645.

Evans, P. D., E. A. Kravitz, B. R. Talamo, and B. G. Wallace (1976a) The association of octopamine with specific neurons along lobster nerve trunks. J. Physiol. (Lond.) 262: 51-70.

Evans, P. D., E. A. Kravitz, and B. R. Talamo (1976b) Octopamine release at two points along lobster nerve trunks. J. Physiol. (Lond.) 262: 71-89.

Gainer, H. (1982) Precursor processing and the neurosecretory vesicle. In Molecular Genetic Neuroscience, F. O. Schmitt, S. J. Bird, and F. E. Bloom, eds., pp. 171-187, Raven Press, New York.

Goldsmith, P. C. (1977) Ultrastructural localization of some hypothalamic hormones. Fed. Proc. 36: 1968-1972.

Goodfriend, T. L., L. Levine, and G. D. Fasman (1964) Antibodies to bradykinin and angiotensin: $\Lambda$ use of carbodiimides in immunology. Science 144: 1344-1346.

Herbert, E., O. Civelli, N. Birnberg, P. Rosa, and M. Uhler (1982) Regulation of expression of pro-opiomelanocortin and related genes in various tissues: Use of cell-free systems and hybridization probes. In Molecular Genetic Neuroscience, F. O. Schmitt, S. J. Bird, and F. E. Bloom, eds., pp. 219-230, Raven Press, New York.

Holman, G. M., and B. J. Cook (1979a) The analytical determination of proctolin by HPLC and its pharmacological action in the stable fly. Comp. Biochem. Physiol. C 62: 231235.

Holman, G. M., and B. J. Cook (1979b) Evidence for proctolin and a second myotropic peptide in the cockroach Leucophaea maderae, determined by bioassay and HPLC analysis. Insect Biochem. 9: 149-154.

Irving, S. N., and T. A. Miller (1980) Octopamine and proctolin mimic spontaneous membrane depolarization in Lucilia larvae. Experientia 36: 566-568.

Kingan, T. G. (1980) Prothoracicotropic hormone, cyclic nucleotides and proctolin in insect central nervous system. Ph.D. thesis, Oregon State University, Corvallis, OR.

Kingan, T. and M. Titmus (1983) Radioimmunologic detection of proctolin in Arthropods. Comp. Biochem. Physiol. C 74 . $75-78$.

Kleinholz, L. H. (1976) Crustacean neurosecretory hormones and physiological specificity. Am. Zool. 16: 151-166.

Kravitz, E. A., S. Glusman, R. M. Harris-Warrick, M. S. Livingstone, T. Schwarz, and M. F. Goy (1980) Amines and a peptide as neurohormones in lobsters: Action on neuromuscular preparations and preliminary behavioral studies. J. Exp. Biol. 89: 159-175.

Lingle, C. J. (1979) The effects of acetylcholine, glutamate, and biogenic amines on muscle and neuromuscular transmission in the stomatogastric system of the spiny lobster, Panulirus interruptus. Ph.D. thesis, University of Oregon, Eugene, OR.

Livingstone, M. S., S. F. Schaeffer, and E. A. Kravitz (1981) Biochemistry and ultrastructure of serotonergic endings in the lobster: Serotonin and octopamine are contained in different nerve endings. J. Neurobiol. 12: 17-54.

Lowry, O. H., N. J. Rosebrough, A. L. Farr, and R. J. Randall (1951) Protein measurement with the Folin phenol reagent. J. Biol. Chem. 193: 265-275.

Martin, S. A., C. E. Costello and K. Biemann (1982) Optimization of experimental procedures for fast atom bombardment mass spectrometry. Anal. Chem. 54: 2362-2368.

May, T. E., B. E. Brown, and A. N. Clements (1979) Experimental studies upon a bundle of tonic fibres in the locust extensor tibiales muscle. J. Insect Physiol. 5: 169-181.

Maynard, D. M., and E. A. Maynard (1962) Thoracic neurosecretory structures in brachyura. III. Microanatomy of peripheral structures. Gen. Comp. Endocrinol. 2: 12-28.

Maynard, D. M., and J. H. Welsh (1959) Neurohormones of the pericardial organs of brachyuran Crustacea. J. Physiol. (Lond.) 199: 215-227.

Miller, M. W. and R. E. Sullivan (1981) Some effects of proctolin on the cardiac ganglion of the Maine lobster, Homarus americanus (Milne Edwards). J. Neurobiol. 12: 629-639.

Miller, R. J., K. J. Chang, B. Cooper, and P. Cuatrecassas (1978) Radioimmunoassay and characterization of enkephalins in rat tissues. J. Biol. Chem. 253: 531-538.

O'Shea, M., and M. E. Adams (1981) Pentapeptide (proctolin) associated with an identified neuron. Science 213: 567-569.

O'Shea, M., and C. A. Bishop (1982) Neuropeptide proctolin associated with an identified skeletal motoneuron. J. Neurosci. 2: 1242-1251.

Piek, T., and P. Mantel (1977) Myogenic contractions in locust muscle induced by proctolin and by wasp, Philanthus triangulum, venum. J. Insect Physiol. 23: 321-325.

Piek, T., B. J. Visser, and P. Mantel (1979) Effect of proctolin, $\mathrm{BPP}_{5 a}$, and related peptides on rhythmic contractions in Locusta migratoria. Comp. Biochem. Physiol. 626: 151-154.

Schwarz, T. L., R. M. Harris-Warrick, S. Glusman, and E. A. Kravitz (1980) A peptide action in a lobster neuromuscular preparation. J. Neurobiol. 11: 623-628.

Skowsky, W. R., and D. A. Fisher (1972) The use of thyroglobulin to induce antigenicity to small molecules. J. Lab. Clin. Med. 80: 134-144.

Starratt, A. N., and B. E. Brown (1975) Structure of the pentapeptide proctolin, a proposed neurotransmitter in insects. Life Sci. 17: 1253-1256.

Sullivan, R. E. (1979) A proctolin-like peptide in crab pericardial organs. J. Exp. Zool. 210: 543-552.

Sullivan, R. E., B. Friend and D. L. Barker (1977) Structure and function of spiny lobster ligamental nerve plexuses: Evidence for synthesis, storage, and secretion of biogenic amines. J. Neurobiol. 8: 581-605.

Udenfriend, S. (1982) A multivalent proenkephalin and its processing. In Molecular Genetic Neuroscience, F. O. Schmitt, S. J. Bird, and F. E. Bloom, eds., pp. 239-247, Raven Press, New York.

Walker, R. J., V. A. James, C. J. Roberts, and G. A. Kerkut (1980) Neurotransmitters in invertebrates. In Receptors for Neurotransmitters, Hormones and Pheromones in Insects. D. B. Sattelle, L. M. Hall, and J. G. Hildebrand, eds., pp. 4157, Elsevier-North Holland Biomedical Press, New York.

Welsh, J. H. (1960) Physiology of the Crustacea, T. H. Waterman, ed., pp. 281-311, Academic Press, New York. 